\title{
Hyponatremia in Rats Induces Downregulation of Vasopressin Synthesis
}

\author{
Alan G. Robinson, Michelle M. Roberts, Wayne A. Evron, Joseph G. Verbalis, and Thomas G. Sherman \\ Departments of Medicine, Behavioral Neuroscience and Psychiatry, School of Medicine, \\ University of Pittsburgh, Pittsburgh, Pennsylvania 15261
}

\begin{abstract}
Hyponatremia due to inappropriate secretion of vasopressin is a common disorder in human pathophysiology, but vasopressin synthesis during hypoosmolality has not been investigated. We used a new method to quantitate synthesis of vasopressin in rats after 3, 7, and $14 \mathrm{~d}$ of hyponatremia induced by administering dDAVP (a vasopressin agonist) and a liquid diet. Vasopressin synthesis was completely turned off by $7 \mathrm{~d}$. Vasopressin mRNA levels in the hypothalamus paralleled the reduction in synthesis and were reduced to levels of only 10-15\% of the content in control rats. When hyponatremia was corrected by withdrawal of DDAVP, vasopressin mRNA slowly returned to normal over $7 \mathrm{~d}$. The observation that vasopressin synthesis can be so completely turned off leads to several conclusions: under normal physiological conditions the neurohypophysis is chronically upregulated; there must be an osmotic threshold for initiation of vasopressin synthesis (and release); the large store of hormone in the posterior pituitary is essential for vasopressin to be available during times of decreased synthesis; and, finally, some nonosmolar stimulus for synthesis must be present during clinical disorders when vasopressin is secreted (and synthesized) despite hypoosmolality. (J. Clin. Invest. 1990. 86:1023-1029.) Key words: vasopressin • oxytocin • neurophysin • hyponatremia • neurohypophysis
\end{abstract}

\section{Introduction}

Hyponatremia is a common clinical problem with reported incidences of $2.5-22 \%$ of hospitalized patients (1-3). It is frequently thought to be due to (or associated with) elevated secretion of arginine vasopressin, a hormone that is synthesized in the supraoptic and paraventricular nuclei of the hypothalamus and is transported to, stored in, and released from the posterior pituitary. The hormone acts on the kidney to increase permeability of water in the collecting duct to cause water retention. With hyperosmolality and/or decreased volume, vasopressin secretion is stimulated, but with hypoosmolality and/or expanded volume, vasopressin secretion is suppressed (4). In many clinical situations of chronic hyponatremia, secretion of vasopressin is not suppressed, but secreted inappropriately relative to plasma osmolality. Thus, in these

Parts of this work were presented at the Association of American Physicians, Washington, DC, 1988; The Endocrine Society, New Orleans, LA, 1988; the Society for Neuroscience, Toronto 1988.

Address reprint requests to Dr. Alan G. Robinson, 930 Scaife Hall, University of Pittsburgh, School of Medicine, Pittsburgh, PA 15261.

Received for publication 22 September 1989 and in revised form 20 March 1990.

J. Clin. Invest.

(C) The American Society for Clinical Investigation, Inc.

$0021-9738 / 90 / 10 / 1023 / 07 \$ 2.00$

Volume 86, October 1990, 1023-1029 situations it appears that vasopressin secretion (and synthesis?) is not downregulated appropriate to the serum $\mathrm{Na}^{+}$. Other physiologic observations also indicate that the neurohypophysis may not readily downregulate its synthesis of vasopressin. The major reason to shut off vasopressin synthesis and secretion is to produce maximum water diuresis. However, since maximum water diuresis is achieved at levels of vasopressin of $0.3-0.5 \mathrm{pg} / \mathrm{ml}$, animals may not need to completely inhibit synthesis and release of vasopressin to permit maximum diuresis (5). Furthermore, vasopressin mRNA levels become elevated two- to fivefold in hypernatremic rats, but when the elevated serum $\mathrm{Na}^{+}$returns to normal the vasopressin mRNA only sluggishly decreases over $2-4$ wk (6-8), suggesting relative insensitivity of synthesis to the decrease in osmolality.

In contrast to reports documenting the response of the neurohypophysis to hypernatremia (6-8), there are few studies of the response of the neurohypophysis to hyponatremia, when secretion of vasopressin is decreased. This is in part because there has been no stable model of long-term hyponatremia in an experimental animal. Humans given excess vasopressin and ad lib. water will develop hyponatremia (9), but rats given vasopressin will decrease water intake and thereby maintain a normal serum sodium concentration (10). To induce acute and chronic hyponatremia in the rat has required administration of vasopressin along with continuous fluid loading by parenteral administration of a hypotonic solution (11). However, one of us (J. G. Verbalis) recently described a protocol in which rats developed and maintained self-induced hyponatremia for long periods during chronic administration of a vasopressin agonist, $\mathrm{dDAVP}$, if the rats were given a dilute liquid nutrient as their only source of calories $(10,12)$. We used this model to study downregulation of vasopressin synthesis in the supraoptic (SON) and paraventricular (PVN) nuclei during hyponatremia and documented that synthesis of vasopressin was turned off. We also studied oxytocin, the other major hormone of the neurohypophysis. Although in most species there is only sporadic need for oxytocin to regulate parturition and lactation (13), in the rat oxytocin is secreted similarly to vasopressin in response to changes in serum osmolality and blood volume (14). Synthesis of oxytocin decreased similarly during hyponatremia, confirming parallel responses of both neurohypophyseal hormones to hypoosmolality as well as hyperosmolality.

\section{Methods}

Animals. Male albino rats of the Sprague-Dawley strain weighing 250-300 g were obtained from Zivic Miller Laboratories (Allison Park, PA). They were individually housed in wire mesh metabolism cages in a temperatures controlled room $\left(21-23^{\circ} \mathrm{C}\right)$ with an 8:00 a.m. to 8:00 p.m. light cycle. During equilibration standard rat chow pellets (Wayne Lab-Blox, Chicago, IL) and tap water were available ad lib. Hypoosmolality was induced using previously described methods (12). The rats were acclimated to a commercial, nutritionally balanced liquid diet formulated for rodents (AIN-76; Bio-Serv, Frenchtown, NJ) 
modified to provide $1.9 \mathrm{kcal} / \mathrm{ml}$. For most days the modified diet was provided in liquid feeding tubes at $50 \mathrm{ml} / \mathrm{d}$, which was calculated to be a weight-maintenance diet. After 3-4 d of the liquid diet, osmotic minipumps (model 2002; Alzet Corp., Palo Alto, CA) containing dDAVP ${ }^{1}$ (desmopressin at a $0.01 \%$ intranasal solution; Rorer Pharmaceuticals, Fort Washington, PA) diluted in $0.15 \mathrm{M} \mathrm{NaCl}$ to a concentration of $10 \mathrm{~g} / \mathrm{ml}$ were implanted subcutaneously along the back under methoxyflurane (Metophane; Pittman-Moore) inhalation anesthesia, resulting in a dDAVP infusion rate of $5 \mathrm{ng} / \mathrm{h}$. On the first day after insertion of the minipumps, the rats were given $100 \mathrm{ml}$ of a 1.0 $\mathrm{kcal} / \mathrm{ml}$ formulation of the liquid diet. From day 2 onward of dDAVP infusion the rats were given $50 \mathrm{ml}$ of the modified concentrated diet as a single morning feeding. Some rats received an identical dDAVP infusion but were maintained on ad lib. water and pelleted rat chow while others were placed on the identical liquid diet but received no dDAVP.

Measured synthesis of vasopressin and oxytocin. Vasopressin is synthesized in the magnocellular neurons of the supraoptic and paraventricular nuclei of the hypothalamus and transported to the posterior pituitary via microtubules (15). Colchicine is well known to disrupt microtubular transport and we recently reported that low doses of colchicine injected into the third ventricle of the hypothalamus of rats blocked transport of vasopressin while synthesis continued (16). For measurement of synthesis, rats were first anesthetized with equithesin $\left(8.5 \mathrm{~g}\right.$ chloral hydrate, $4.25 \mathrm{~g} \mathrm{MgSO}_{4}, 1.96 \mathrm{~g}$ pentobarbital sodium in $200 \mathrm{ml}$ water) given intra-peritoneally a dose of $0.3 \mathrm{ml}$ per $100 \mathrm{~g}$ body weight to provide $30-60 \mathrm{~min}$ anesthesia with negligible morbidity. They were then placed in a Kopf DKI 900 small animal stereotactic frame with the tooth bar fixed at $-3.3 \mathrm{~mm}$. The skin overlying the skull was shaved and cleaned with alcohol and a sharp dissection made in the midline. Soft tissue was cleared away from the skull by blunt dissection and a small hole made with an 18-gauge needle in the midline $1 \mathrm{~mm}$ posterior of the bregma. The small amount of bleeding was tamponaded when a 0.25 -in. O.D. needle attached to a $5-\mu l$ syringe (model 7105; Hamilton Instruments, Reno, NV) was lowered vertically to a level $8.5 \mathrm{~mm}$ below the surface of the skull. Colchicine (Sigma Chemical Co., St. Louis, MO), $7 \mu \mathrm{g}$, was injected in $1 \mu \mathrm{l}$ $0.15 \mathrm{M} \mathrm{NaCl}$ at a rate of $0.1 \mu \mathrm{l}$ every $10 \mathrm{~s}$. After injection, the hole in the skull was sealed with bone wax (Ethicon, Somerville, NJ), the skin was closed with clips, and the animals were kept warm until they recovered from anesthesia when they were returned to their cages. As reported previously (16), with this dose of colchicine animals awoke from anesthesia normally and showed no change in behavior. Published studies have documented a linear accumulation of vasopressin and oxytocin in the hypothalamus of control animals from 0 to $18 \mathrm{~h}$ after injection (16). Groups of rats were killed at $0 \mathrm{~h}$ of colchicine injection and 12-18 h after injection of colchicine. Synthesis rate of hormone was determined by the difference in content of hormone in the hypothalamus at the two time points divided by the number of hours of blocked transport. The hourly rate of synthesis with this method in normal rats is $1.2-1.9 \mathrm{pmol} / \mathrm{h}$ for vasopressin, $1.4-2.5$ $\mathrm{pmol} / \mathrm{h}$ for oxytocin, and 3.8-4.3 pmol/h for neurophysin (16).

Tissue extraction. After the mice were decapitated the skin overlying the skull was removed and the skull was cut with scissors. The brain was lifted to expose the optic nerves which were cut and the brain was then removed, inverted, and placed in a modified Jacobowitz slicer (17) (Zivic Miller Laboratories). Vertical razor blade cuts just rostral to the optic chiasm and just rostral to the mammillary bodies were made and this thick section of hypothalamus laid on a sterile petri dish. For assay of peptides, freehand cuts were made at the top of the third ventricle and lateral of the hypothalamic sulci to produce a wedge of hypothalamus containing all of the supraoptic nuclei and paraventricular nuclei and the tracts to the pituitary stalk. Each individual wedge of hypothalamus was homogenized in a ground glass tissue homoge-

1. Abbreviations used in this paper: dDAVP, desmopressin; PVN, paraventricular nuclei; SON, supraoptic nuclei. nizer with $1 \mathrm{ml} 0.1$ normal $\mathrm{HCl}$ at $4^{\circ} \mathrm{C}$ with an additional $1 \mathrm{ml}$ used to rinse the pestle and homogenizer.

For extraction of mRNA the brain was handled similarly with the exception that in addition to the razor blade at the optic chiasm and anterior to the mammillary bodies, a third razor blade was lowered to bisect this section of hypothalamus. The two slices of hypothalamus were laid open on a petri dish in an open-book fashion and using a razor blade the two supraoptic nuclei and paraventricular nuclei were cut out free hand. The remaining sections have been confirmed to contain no supraoptic or paraventricular magnocellular nuclei by immunohistology. Similar methods have been published to demonstrate up regulation of vasopressin mRNA with hyperosmolality in rats (18). The paired supraoptic nuclei and paraventricular nuclei were dropped into plastic snap-top vials (Fisher Scientific, Pittsburgh, PA) quick frozen on dry ice, and stored at $-70^{\circ}$ overnight for extraction the next day.

RIAS. Acid extracts of tissue were appropriately diluted in $0.1 \mathrm{M}$ phosphate buffer $\mathrm{pH} 7.4$ and assayed at multiple dilutions. Plasma was either collected from trunk blood or (for repeat samples) from an indwelling jugular venous catheter. Silastic tubing ( $1.19 \mathrm{~mm}$ o.d.; Dow Corning, Midland, MI) was inserted into the jugular vein to the level of the right atrium and connected to a link of polyethylene tubing (PE-60; Clay Adams Div., Parsippany, NJ) that was tunneled to an opening in the skin between the scapulas. The catheter was filled with providoneheparin solution (Eastman Kodak Co., Rochester, NY) which was removed and the catheter flushed with $0.15 \mathrm{M} \mathrm{NaCl} 30-60 \mathrm{~min}$ before drawing a blood sample. Blood samples of $1-1.5 \mathrm{ml}$ were withdrawn over 15-30 s into disposable plastic syringes and immediately transferred to iced borosilicate tubes containing $143 \mathrm{U}$ heparin (BD vacutainer, Rutherford, NJ). Blood removed was replaced with an equal volume of $0.15 \mathrm{M} \mathrm{NaCl}$ with packed red blood cells from the sample.

Plasma samples for oxytocin and vasopressin were extracted as previously described and measured with RIAs established in our laboratory $(19,20)$. The assay for rat neurophysin measures total neurophysin and is not specific for vasopressin/neurophysin or oxytocin/ neurophysin (21). Blood samples for $\mathrm{Na}^{+}$determination were centrifuged at $4^{\circ} \mathrm{C}$ and the plasma removed for plasma sodium measured on an electrolyte 2 analyzer (Beckman Instrument Co., Fullerton, CA).

Quantitation of $m R N A$. Solution hybridization was performed as previously described (18). Tissue biopsies of supraoptic and paraventricular nuclei were homogenized in $0.3 \mathrm{ml}$ LET buffer $(10 \mathrm{mM}$ Tris$\mathrm{HCl}$, PH 7.5, $10 \mathrm{mM}$ EDTA, and $1 \%$ [wt/vol] of $36.7 \mathrm{mM}$ lithium dodecylsulfate containing $0.1 \mathrm{mg} / \mathrm{ml}$ proteinase $\mathrm{K}$ ) and incubated at $37^{\circ} \mathrm{C}$ for $60 \mathrm{~min}$. The homogenate was extracted with 1 vol buffered phenol, once with phenol/chloroform, and once with chloroform. Nucleic acids were precipitated with $70 \%$ ethanol at $-20^{\circ} \mathrm{C}$. Solution phase hybridization RNase protection assay was performed using RNA complementary to endogenous vasopressin RNA. The cRNA was prepared from linearized pGEM plasmid containing AVP CDNA insert corresponding to nucleic acids $190-586$ of the rat vasopressin cDNA (18). Hybridizations were conducted in $30-\mu$ l volumes at $85^{\circ} \mathrm{C}$ for $5 \mathrm{~min}$ and $50^{\circ} \mathrm{C}$ for $5 \mathrm{~h}$. RNA digestion was performed at $22^{\circ} \mathrm{C}$ for $120 \mathrm{~min}$ in $10 \mathrm{mM}$ Tris- $\mathrm{HCl} \mathrm{pH} 7.5,5 \mathrm{mM}$ EDTA, $0.2 \mathrm{M} \mathrm{NaCl}$, and $0.1 \mathrm{M}$ lithium chloride containing $40 \mathrm{mg} / \mathrm{ml}$ RNase A (Sigma Chemical Co.) and 1,000 U/ml RNase T1 (Bethesda Research Laboratories, Gaithersburg, MD). Protected fragments were recovered by phenol/ chloroform extraction and precipitation in ethanol. Protected cRNA:mRNA fragments were fractionated on $4 \%$ polyacrylamide gels (18). The concentration of AVP mRNA was calculated using optical density determined by a Loats image analysis system. Optical density was correlated with actual disintegrations per minute of clean bands that could be scraped from the glass plate, hydrolyzed, neutralized and counted in scintillation vials. The correlation of optical density and disintegrations per minute was $r>0.995$. Disintegrations per minute were converted to mole equivalents based on specific activity of the cRNA probe, the frequency of labeled nucleotide, and the deduced sequence of the protected cRNA band (18). Results are expressed as total mRNA per rat. 


\section{Results}

Hyponatremia. Stable hyponatremia was demonstrated in 11 rats treated for $14 \mathrm{~d}$ with $\mathrm{dDAVP}$ and liquid diet, while vehicle-treated controls on the same diet had no change in serum sodium (Fig. 1). Plasma sodium in the 24 experimental rats used to quantitate synthesis of vasopressin on days $0,3,7$, and 14 of hyponatremia are also illustrated in Fig. 1. Baseline sodium in rats at day 0 was $140.6 \pm 0.3 \mathrm{mmol} / \mathrm{liter}$ and the range of serum sodium in all experimental rats was between 108 and $115 \mathrm{mmol} /$ liter. Experimental rats were significantly hyponatremic relative to controls at all time points tested after day 0 $(P<0.01)$. Hyponatremic rats maintained their weight over the $14 \mathrm{~d}: 294 \pm 3 \mathrm{~g}$ at day 0 , and $307 \pm 3,302 \pm 3$, and $312 \pm 3 \mathrm{~g}$ at 3,7 , and $14 \mathrm{~d}$ of hyponatremia, respectively. For 24 rats given liquid diet without dDAVP, serum $\mathrm{Na}^{+}$at day 14 was $141 \pm 0.9$ $\mathrm{mmol} / \mathrm{liter}$, a value not different from control rats. Weights at day 0 and 14 were $309 \pm 3$ and $331 \pm 2$ g. For 24 rats given dDAVP but ad lib. diet serum $\mathrm{Na}^{+}$at day 14 was $137 \pm 0.5$ $\mathrm{mmol} / \mathrm{liter}$, slightly less than control, $P<0.01$. These rats on ad lib. diet gained more weight than the other groups over the $14 \mathrm{~d}$, increasing from $298 \pm 2$ to $461 \pm 3 \mathrm{~g}$.

Synthesis of neurohypophyseal peptides. Hourly synthesis of vasopressin, oxytocin and neurophysin at $0,3,7$, and 14 days of hyponatremia is illustrated in Fig. 2. As previously described (16), synthesis rates were determined by comparing mean hypothalamic peptide at baseline versus content postcolchinine blockade. These two means were significantly different by $t$ test $P<0.05$ for vasopressin at day 0 and 3 and for both oxytocin and neurophysin at day 0,3 , and 14 . Differences in content of vasopressin at 7 and $14 \mathrm{~d}$, although arithmetically negative, were not significantly different, i.e., unmeasurable synthesis. Values for neurophysin are divided in half because vasopressin/neurophysin and oxytocin/neurophysin are measured together by this assay. There was good agreement between the decrease of hormone synthesis and the decrease of neurophysin synthesis with hyponatremia. The more sluggish response of neurophysin probably reflected the lesser decrease in synthesis of oxytocin.

Rats given liquid diet without dDAVP had a calculated synthesis rate of $1.4 \mathrm{pmol} / \mathrm{h}$ for vasopressin, $1.3 \mathrm{pmol} / \mathrm{h}$ for oxytocin, and $2.3 \mathrm{pmol} / \mathrm{h}$ for neurophysin $(\div 2)$. Rats given

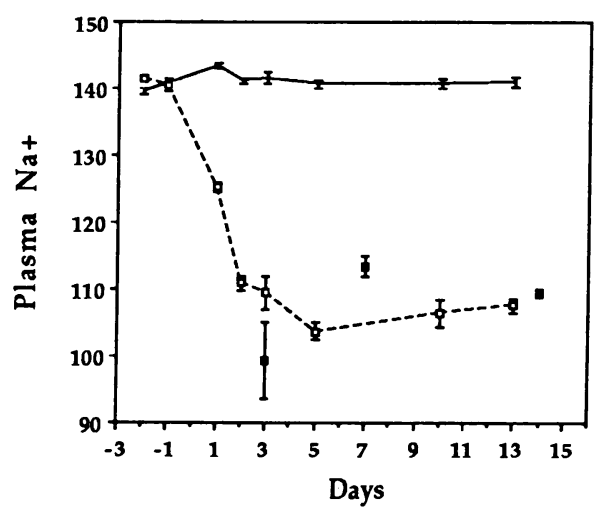

Figure 1. Plasma $\mathrm{Na}^{+}$concentration in rats made hyponatremic with dDAVP and liquid diet (open squares) versus vehicle-treated controls (solid line). The $\left[\mathrm{Na}^{+}\right]$in rats studied in Fig. 2 are illustrated as unconnected solid squares.

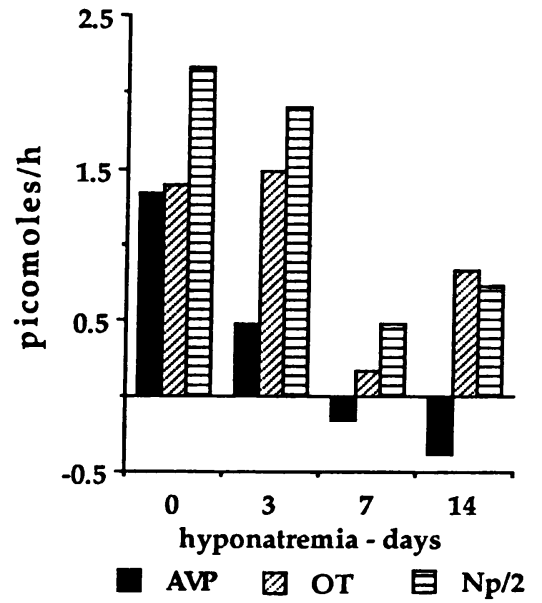

Figure 2. Hourly synthesis of vasopressin, oxytocin and neurophysin at baseline and after 3,7 , and $14 \mathrm{~d}$ of hyponatremia. Rats $(n=12)$ were killed at baseline and after $18 \mathrm{~h}$ of blocked transport of vasopressin from the hypothalamus to the posterior pituitary. The difference between the hypothalamic content of the two groups of rats divided by the hours between killing is a direct measure of synthesis. Because the bars represent a difference between two means, the values have no variance.

dDAVP with ad lib. water and rat chow had a calculated synthesis rate of $2.2 \mathrm{pmol} / \mathrm{h}$ for vasopressin, $2.2 \mathrm{pmol} / \mathrm{h}$ for oxytocin, and $5 \mathrm{pmol} / \mathrm{h}$ for neurophysin $(\div 2)$. Although the rates for the dDAVP-treated rats are slightly above the day 0 synthesis rates in these studies, this is likely explained by the nearly $50 \%$ greater weight of the rats in this group by the time of killing. Regardless, both control groups had synthesis rates markedly in excess of the hyponatremic rats (see Fig. 1).

Quantitation of neurohypophyseal $m R N A$. Vasopressin and oxytocin mRNA were measured in rats maintained as above and decapitated after $0,3,7$, and $14 \mathrm{~d}$ of hyponatremia. Samples from individual rats' supraoptic and paraventricular nuclei were run on polyacrylamide gels in groups of four to include sequentially a $0-, 3-, 7-$, and 14-d rat. An autoradiograph of hybridized vasopressin mRNA samples from the supraoptic nuclei is illustrated in Fig. 3. A decrease in vasopressin mRNA is apparent at $3 \mathrm{~d}$ and there was a further decrease at 7 and $14 \mathrm{~d}$ of hyponatremia. Of interest is the mRNA of the rats to the right of Fig. 3 in which the 7- and 14-d hyponatremic rats did not show the same decreased vasopressin mRNA. These two rats both had normal plasma sodium values at killing, probably due to malfunction of the osmotic minipump that was used to infuse the dDAVP. They do, however, augment the data on the dietary controls shown earlier and demonstrate that forced fluid intake alone was not sufficient to produce downregulation of vasopressin mRNA in the absence of hyponatremia.

Neurophysins are part of the precursor hormone for vasopressin and oxytocin and although the neurophysins are hormone specific, they are identical in the midportion (exon B) of the prohormones (18). As the riboprobe used in the study was a near full-length vasopressin riboprobe, there is hybridization in solution to the midportion of the oxytocin mRNA, but there is only a partial match for oxytocin so the resulting dimer is shorter and less radioactive. The faint bands noted on the lower portion of the vasopressin gel are the oxytocin mRNA. 


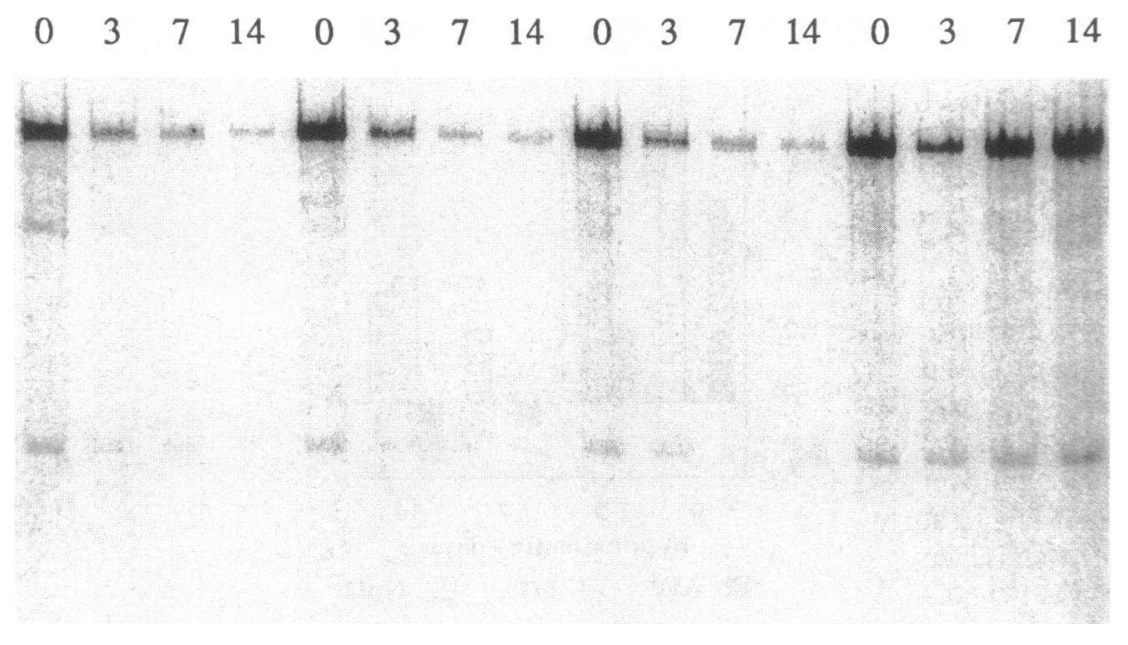

Figure 3. Autoradiograph of mRNA:cRNA hybrids from individual supraoptic nuclei of rats after $0,3,7$, and $14 \mathrm{~d}$ of hyponatremia. The decrease of AVP mRNA with duration of hyponatremia is apparent. The rats on days 7 and 14 on the extreme right of the gel did not become hyponatremic and have no decrease in AVP mRNA. The faint bands at the bottom of the gel are due to cross-hybridization of the vasopressin cRNA with homologous nucleotide sequences in oxytocin mRNA.
However, for quantitation of oxytocin a full-length riboprobe for oxytocin was used and in these gels (not shown) the relative positions of the oxytocin mRNA and the vasopressin mRNA were reversed.

The percentage change of vasopressin mRNA in the supraoptic and paraventricular nuclei is illustrated in Fig. 4. There was a $>50 \%$ reduction in vasopressin mRNA by the third day and $>85 \%$ reduction by day 14 . Vasopressin mRNA in the paraventricular nucleus showed a pattern similar to the supraoptic nucleus although the total content was less. At baseline the vasopressin mRNA content in the supraoptic nuclei was $281.3 \pm 13.6\left(\times 10^{-18} \mathrm{~mol}\right)$ while in the paraventricular nuclei it was $50.9 \pm 15.8\left(\times 10^{-18} \mathrm{~mol}\right)$ consistent with previous reports that the SON contains more vasopressin neurons (22). An analysis of the parallel decay profiles of vasopressin mRNA in the PVN and SON both indicate a close fit to first-order kinetics with a $k=3.6 / \mathrm{h}$ and maximum apparent half-life of $\sim 4.6 \mathrm{~d}$. For oxytocin mRNA the content at day 0 in the supraoptic nuclei was $8.2 \pm 9.7\left(\times 10^{-18} \mathrm{~mol}\right)$ and in the paraventricular nuclei $57.01 \pm 16.8\left(\times 10^{-18} \mathrm{~mol}\right)$. The percent changes in oxytocin mRNA, are illustrated in Fig. 5. The changes are less dramatic for oxytocin mRNA which was decreased by 37 at $3 \mathrm{~d}, 60$ at $7 \mathrm{~d}$, and $69 \%$ at $14 \mathrm{~d}$, values that nonetheless are consistent with the less dramatic decrease in oxytocin synthesis rates described above.

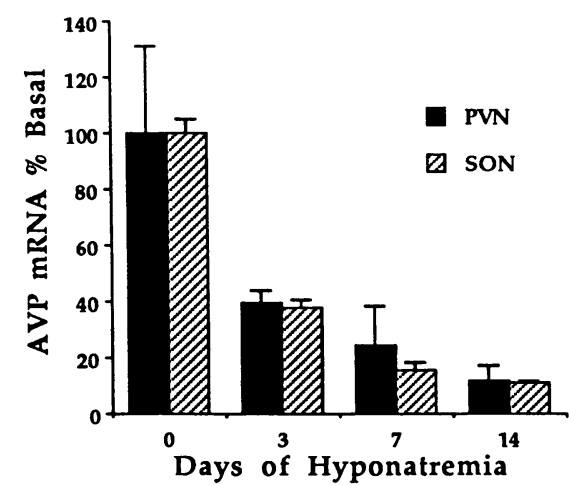

Figure 4. Content of vasopressin mRNA in paired supraoptic (SON) and paraventricular (PVN) nuclei of rats with 3,7 , and $14 \mathrm{~d}$ of hyponatremia expressed as a percentage \pm SEM of control $(0 \mathrm{~d}) ; n=4$.
To determine how long the mRNA would remain decreased when the hyponatremia was reversed, rats were made similarly hyponatremic for $7 \mathrm{~d}$ and then the infusion of dDAVP was terminated by removing the pumps and the diet was changed to ad lib. access to pelleted rat chow and water. With this paradigm serum $\mathrm{Na}^{+}$returns to normal in $24-48 \mathrm{~h}$ (12), and all of the rats in this study achieved a normal serum $\mathrm{Na}^{+}$by killing. Vasopressin and oxytocin mRNA was quantitated at $7 \mathrm{~d}$ of hyponatremia (which is considered day 0 of recovery) and also at 2, 4, and $7 \mathrm{~d}$ of recovery. Total hypothalamic vasopressin mRNA (supraoptic nucleus + paraventricular nucleus) expressed as a percentage of basal was: $17 \pm 2$ at day $0(n=5) ; 33 \pm 6$ at day $2(n=4) ; 67 \pm 8$ at day $4(n=5)$; and $86 \pm 11 \%$ at day $7(n=3)$. For oxytocin mRNA the values were: $56 \pm 6$ at day $0 ; 69 \pm 3$ at day $2 ; 60 \pm 4$ at day 4 ; and $84 \pm 7 \%$ at day 7 .

\section{Discussion}

These studies demonstrate that with decreased need for vasopressin secretion there is decreased vasopressin synthesis. This was a physiologic response to the hyponatremia because synthesis of vasopressin was not decreased by administration of dDAVP alone nor with the liquid diet alone. Interestingly, some studies have indicated that the natural hormone, AVP,

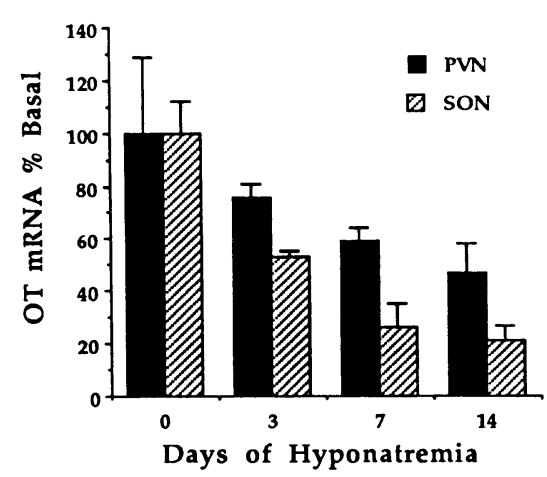

Figure 5. Content of oxytocin mRNA in paired supraoptic (SON) and paraventricular (PVN) nuclei of rats with 3,7 , and $14 \mathrm{~d}$ of hyponatremia expressed as a percentage \pm SEM of control $(0 \mathrm{~d}) ; n=4$. 
inhibits recovery of damaged vasopressinergic neurons independent of osmolality $(23,24)$, and a modest decrease in mRNA has been reported with vasopressin infusion (25). We saw no effect of dDAVP alone to decrease vasopressin synthesis. Whether this difference is due to the low levels of dDAVP which are sufficient to cause maximum water retention, lack of dDAVP stimulation of $V_{1}$ receptors (26), or some metabolic effect is not known. Regardless, the data are conclusive that the decreased synthesis of vasopressin and corresponding decreased vasopressin mRNA was due to the hyponatremia. Thus, it is now documented that the neurohypophysis responds to hypoosmolality via down regulation of synthesis as it does to hyperosmolality via upregulation of synthesis. Furthermore, just as the increased levels of mRNA induced by hyperosmolality require up to $2 \mathrm{~d}$ for full expression, the decrease in vasopressin mRNA after establishment of hypoosmolality is sluggish. Both observations would be consistent with a relatively long $t_{1 / 2}$ of vasopressin mRNA. An analysis of the parallel decay profiles of vasopressin mRNA in the PVN and SON indicate a close fit to first-order kinetics with $k=3.6 / \mathrm{h}$. While an exact $t_{1 / 2}$ can not be reliably calculated from these data where synthesis of new mRNA is only presumed to be absent, we can say that the maximum apparent half life of vasopressin mRNA is $\sim 4.6 \mathrm{~d}$. This maximum is considerably shorter than the half-life based upon return to normal of elevated vasopressin mRNA in some studies hypernatremic rats (8), but it is considerably longer than the reported half-life of vasopressin mRNA in the suprachiasmatic nucleus (27-29). It is possible that the true half-life of vasopressin mRNA in the magnocellular neurons is shorter than that calculated from our studies as it may require more than one day for the animals to become maximally hyponatremic, and it is not known what degree of hyponatremia is necessary to completely inhibit transcription of new mRNA. We have reported preliminary results using nuclear run-on measurements, however, and transcription of vasopressin and oxytocin message was reduced to unmeasurable levels at this degree of hyponatremia, so it is likely that mRNA was not being synthesized.

Within the range of mRNA levels measured in the present studies there was a good correlation between the rate of synthesis of vasopressin and the level of vasopressin mRNA ( $r$ $=0.95$ ). Other preliminary data show that the same linear relation extends to hypernatremic rats $(30)$. This linear relationship is interpreted to indicate that the major regulation of synthesis of vasopressin is at the level of mRNA, with a relatively constant subsequent translation rate per mole of mRNA. While our data are most consistent with transcription of message as the primary control point of vasopressin synthesis, we can not exclude that post-transcriptional modification of mRNA, e.g., poly A tail extension $(31,32)$ might produce changes in mRNA content by changing degradation rate.

The nadir of vasopressin mRNA levels was not reached for several days, at which time a small amount of mRNA was still measurable. We interpret the low levels of vasopressin mRNA at 7 and $14 \mathrm{~d}$ as representing only background activity, but here also we can not exclude low levels of mRNA which are not being transcribed nor low levels of "futile" translation of peptide in which new hormone is rapidly destroyed and not detected by our method of measuring synthesis. However, newly synthesized vasopressin precursor is immediately packaged into neurosecretory granules (15) and cleavage of the precursor to mature hormone takes place within granules. De- struction of newly synthesized vasopressin in a "futile" process would, therefore, likely occur in granules, and we found no evidence of vasopressin degradation in the posterior pituitary granule pool over the same time frame (30).

In the studies in which hyponatremic rats were allowed to recover from the hypoosmolality, vasopressin mRNA returned to normal only slowly over $7 \mathrm{~d}$. This is similar to studies of normonatremic rats made hypernatremic, in which vasopressin mRNA was not significantly elevated until $36-48 \mathrm{~h}$ (6-8). These various observations can be interpreted to provide an explanation for the large store of hormone in the posterior pituitary. This store allows the animal to satisfy acute needs for vasopressin by releasing preformed hormone during the time it takes to initiate transcription and to increase translational activity.

The data reported here also lend support to the concept of an osmotic threshold for vasopressin release. Based on measurement of plasma vasopressin levels, it has been debated whether there was a discrete osmotic threshold for release of vasopressin or whether there was a logarithmic relationship between plasma osmolality and plasma vasopressin release (33-35). In the latter case, one would expect that vasopressin secretion, and hence synthesis, would never be completely turned off. However, the data presented here indicate that vasopressin synthesis can be turned off, thus providing support on a molecular level for the concept of an osmotic threshold. With the knowledge that synthesis of vasopressin can be so dramatically decreased with hyponatremia, we suggest that a normal rat, which maintains easily measurable vasopressin mRNA levels, must have a chronically stimulated (upregulated) system. This is consistent with the fact that all terrestrial animals are chronically threatened by dehydration and must maintain active secretion of vasopressin. This observation is also consistent with the idea that under normal conditions animals function in the midrange of their vasopressin/osmolality relationship, neither maximally stimulated nor maximally suppressed.

The physiologic role of oxytocin in regulation of osmolality in the rat has not been completely defined $(14,36)$, but the studies reported here again demonstrate that in the rat, unlike other animals, there are changes in secretion, synthesis and transcription of oxytocin similar to that of vasopressin in response to changes in serum sodium concentration. The downregulation of oxytocin in our studies, like vasopressin, was likely a physiologic response to hyponatremia and not a pharmacologic response to dDAVP, because even when arginine vasopressin was reported to inhibit recovery of vasopres:sinergic neurons in the studies noted above $(23,24)$, the infusion did not inhibit the recovery of damaged oxytocinergic neurons.

The results reported here provide some insight into the common clinical problem of hyponatremia in which plasma vasopressin is elevated despite hypoosmolality. While inappropriate secretion of vasopressin has some well recognized causes, e.g., secretion of vasopressin by carcinoma of the lung (37); when the vasopressin secretion is from the neurohypophysis, the stimulus for secretion is often undetermined. Our findings that vasopressin synthesis (mRNA) is so completely downregulated by hypoosmolality indicate that to maintain transcription of message and translation of vasopressin requires some other ongoing excitatory stimulus. It is well recognized that the input to the neurohypophysis is bimodal 
(38-40); an osmotic input that primarily responds to plasma osmolality and a baroreceptor or volume receptor stimulus that includes high-pressure receptors sensing blood pressure and low-pressure receptors sensing plasma or extracellular fluid volume. The osmolar stimulus is generally considered to be more sensitive to small changes, but the volume receptor system is capable of producing higher plasma levels of vasopressin when maximally stimulated $(38,39,41)$. In clinical situations, when secretion of vasopressin is inappropriate to the hyponatremia there must also be some ongoing excitatory stimulus to override the downregulation that would otherwise be produced by the hyponatremia. One possible source of such stimuli is baroreceptor or volume receptor activation. Indeed, in two large clinical studies of hyponatremia with excess vasopressin levels; renin levels and pulse indicated that there was "appropriate" baroreceptor stimulation of vasopressin $(1,42)$. Similar baroreceptor stimulation was reported in specific reports of hyponatremia in cirrhosis (43) and congestive heart failure (44). The experimental model of hyponatremia we used does not separate the two types of input because the hyponatremia in these rats is associated with volume expansion, so both osmotic-induced and volume-induced stimuli to vasopressin release should be inhibited $(12,41)$. In future studies it will be of interest to determine which of these two inputs provides a stronger stimulus for vasopressin mRNA transcription, and whether baroreceptor stimulation will overcome the downregulation produced by hypoosmolality.

\section{Acknowledgments}

Laboratory assistance was provided by D. Sipula and M. Drutarosky and secretarial support by M. Bolek, J. Hasch, and M. Altvater.

The studies were supported by National Institutes of Health grants AM-16166, DK-38094, F32 MH-09239, and PO1 422251.

\section{References}

1. Anderson, R. J., H.-M. Chung, R. Kluge, and R. W. Schrier. 1985. Hyponatremia: a prospective analysis of its epidemiology and the pathogenetic role of vasopressin. Ann. Intern. Med. 102:164-168.

2. Flear, C. T. G., G. V. Gill, and J. Burn. 1981. Hyponatremia: mechanisms and management. Lancet. ii:26-81.

3. Kleinfeld, M., M. Casimir, and S. Borra. 1979. Hyponatremia as observed in a chronic disease facility. J. Am. Geriatr. Soc. 27:156-161.

4. Verbalis, J. G., E. F. Baldwin, and A. G. Robinson. 1986. Osmotic regulation of vasopressin and oxytocin secretion following sustained hyponatremia. Am. J. Physiol. 250(Regul. Integr. Comp. Physiol.). R444-R451.

5. Vokes, T., and G. L. Robertson. 1985. Physiology of secretion of vasopressin. In Diabetes Insipidus in Man (Frontiers of Hormone Research). P. Czernichow and A. G. Robinson, editors. Karger, Basel. 127-155.

6. Sherman, T. G., H. Akil, and S. J. Watson. 1985. Vasopressin mRNA expression: a northern and in situ hybridization analysis. In Vasopressin. R. W. Schrier, editor. Raven Press, New York. 475-483.

7. Majzoub, J. A. 1985. Vasopressin biosynthesis. In Vasopressin, R. W. Schrier, editor. Raven Press, New York. 465-474.

8. Zingg, H. H., D. Lefebvre, and G. Almazan. 1986. Regulation of vasopressin gene expression in rat hypothalamic neurons. J. Biol. Chem. 261:12956-12959.

9. Leaf, A., F. C. Bartter, R. F. Santos, and O. Wrong. 1953. Evidence in man that urinary electrolytes loss induced by Pitresisin is a function of water retention. J. Clin. Invest. 32:868-878.
10. Verbalis, J. G. 1984. An experimental model of syndrome of inappropriate antidiuretic hormone secretion in the rat. Am. J. Physiol. 247:E540-E553.

11. Gross, P. A., and R. J. Anderson. 1982. Effects of DDAVP and AVP on sodium and water balance in conscious rat. Am. J. Physiol. 243 (Regul. Integra. Comp. Physiol. 12):R512-519.

12. Verbalis, J. G., and M. D. Drutarosky. 1988. Adaptation to chronic hypoosmolality in rats. Kidney Int. 34:351-360.

13. Amico, J. A., and A. G. Robinson, editors. 1985. Oxytocin: Clinical and Laboratory Studies. Elsevier Science Publishers, Amsterdam, The Netherlands.

14. Balment, R. J., M. J. Brimble, and M. L. Forsling. 1980. Release of oxytocin induced by salt loading and its influence on renal excretion in the male rat. J. Physiol. (Lond.). 308:439-449.

15. Gainer, H., Y. Sarene, and M. J. Brownstein. 1977. Biosynthesis and axonal transport of rat neurohypophysial proteins and peptides. J. Cell Biol. 73:366-381.

16. Robinson, A. G., M. M. Roberts, W. A. Evron, L. E. Janocko, and G. E. Hoffman. 1989. Total translation of vasopressin and oxytocin in the neurohypophysis of the rat. Am. J. Physiol. 257:R109-117.

17. Jacobowitz, D. M. 1974. Removal of discrete fresh regions of rat brain. Brain Res. 80:111-115.

18. Sherman, T. G., and S. J. Watson. 1988. Differential expression of vasopressin alleles in the Brattleboro heterozygote. J. Neurosci. 8:3797-3811.

19. Seif, S. M., A. G. Robinson, T. V. Zenser, B. B. Davis, A. B. Huellmantel, and C. Haluszczak. 1979. Neurohypophysial peptides in hypothyroid rats: plasma levels and kidney response. Metab. Clin. Exp. 28:137-143.

20. Verbalis, J. G., E. F. Baldwin, and A. G. Robinson. 1986. Osmotic regulation of vasopressin and oxytocin secretion following sustained hyponatremia. Am. J. Physiol. 250(Regul. Integr. Comp. Physiol.). R444-R451.

21. Seif, S. M., A. B. Huellmantel, M. P. Platia, C. Haluszczak, and A. G. Robinson. 1977. Isolation, radioimmunoassay and physiologic secretion of rat neurophysins. Endocrinology. 100:1317-1326.

22. Zimmerman, E. A., and A. G. Robinson. 1976. Hypothalamic neurons secreting vasopressin and neurophysin. Kidney Int. 10:12-24.

23. Herman, J. P., F. F. Marciano, S. J. Wiegand, and D. M. Gash. 1987. Selective cell death of magnocellular vasopressin neurons in neurohypophysectomized rats following chronic administration of vasopressin. J. Neurosci. 7:2564-2575.

24. Van Tol, H. H. M., J. Z. Kiss, and J. P. H. Burbach. 1989. Differential responses in vasopressin and oxytocin gene expression in distinct hypothalamic nuclei after hypothalamoneurohypophyseal disconnection and vasopressin substitution. Neuroendocrinology. 49:337-343.

25. Rehbein, M., M. Hillers, E. Mohr, R. Ivell, S. Morley, H. Schamle, and D. Richter. 1986. The neurohypophyseal hormones vasopressin and oxytocin. Hoppe-Seyler's Z. Physiol. Chem. 367:695704.

26. Robinson, A. G. 1976. DDAVP in the treatment of central diabetes insipidus. N. Engl. J. Med. 294:507.

27. Uhl, G. R., and S. M. Reppert. 1986. Suprachiasmatic nucleus vasopressin messenger RNA: circadian variation in normal and brattleboro rats. Science (Wash. DC). 232:390-393.

28. Carter, D. A., and D. Murphy. 1989. Diurnal rhythm of vasopressin messenger-RNA species in the rat suprachiasmatic nucleusindependence of neuroendocrine modulation and maintenance in explant culture. Mol. Brain Res. 6:233-239.

29. Burbach, J. P., Bin Liu, T. A. M. Voorheris, and H. H. M. Van Tol. 1988. Diurnal variation in vasopressin and oxytocin messenger RNA's in hypothalamic nuclei of the rat. Mol. Brain Res. 4:157-160.

30. Roberts, M. M., G. E. Hoffman, T. G. Sherman, and A. G. Robinson. 1989. Evidence for vasopressin synthesis/transport coupling in the rat neurohypophysis. 71st Annual Meeting of the Endocrine Society, Seattle, WA. No. 962, p. 263. (Abstr.)

31. Zingg, H. H., D. L. Lefebvre, and A. Guillermina. 1988. Regu- 
lation of Poly(A) trail size of vasopressin mRNA. J. Biol. Chem 263:11041-11043.

32. Carrazana, E. J., K. B. Pasieka, and J. A. Majzoub. 1988. The vasopressin mRNA Poly(A) tract is unusually long and increases during stimulation of vasopressin gene expression in vivo. $\mathrm{Mol}$. Cell Biol. 8:2267-2274.

33. Weitzman, R. E., and D. A. Fisher. 1977. Log linear relationship between plasma arginine vasopressin and plasma osmolality. $\mathrm{Am}$. J. Physiol. 233:E37-E40.

34. Rodbard, D., and P. J. Munson. 1977. Is there an osmotic threshold for vasopressin release? Am. J. Physiol. 234:E340-E342.

35. Moses, A. M. 1977. Is there an osmotic threshold for vasopressin release? Am. J. Physiol. 234:E339-E340.

36. Verbalis, J. G., M. Mangione, E. M. Stricker, D. D. Smith, and V. Hruby. 1989. Oxytocin natriuresis occurs at physiological concentrations via an oxytocin receptor-mediated mechanism. Clin. Res. 37:536A. (Abstr.)

37. Amatruda, T. T., P. J. Mulrow, J. C. Gallagher, and W. H. Sawyer. 1963. Carcinoma of the lung with inappropriate antidiuresis. N. Engl. J. Med. 269:544-549.

38. Vokes, T., and G. L. Robertson. 1985. Physiology of secretion of vasopressin. In Diabetes Insipidus in Man (Frontiers of Hormone Research) P. Czernichow and A. G. Robinson, editors. Karger, Basel. 127-155.

39. Robertson, G. L. 1977. The regulation of vasopressin function in health and disease. Recent Prog. Horm. Res. 33:333-385.

40. Schrier, R. W., T. Berl, and R. J. Anderson. 1979. Osmotic and nonosmotic control of vasopressin release. Am. J. Physiol. 236:F321F332.

41. Verbalis, J. G., M. D. Drutarosky, R. J. Ertel, and R. R. Vollmer. 1989. Adaptive responses to sustained volume expansion in hyponatremic rats. J. Endocrinol. 122:421-431.

42. Gross, P., H. Pehrisch, W. Rascher, E. Hackenthal, Schömig, and E. Ritz. 1986. Vasopressin in hyponatremia: What Stimuli? J. Cardiovasc. Pharmacol. 8(Suppl. 7):S92-S95.

43. Bichet, D. G., V. J. Van Putten, and R. W. Schrier. 1982. Potential role of increased sympathetic activity in impaired sodium and water excretion in cirrhosis. N. Engl. J. Med. 307:1552-1557.

44. Schrier, R. W. and D. G. Bichet. 1981. Osmotic and nonosmotic control of vasopressin release and the pathogenesis of impaired water excretion in adrenal, thyroid and edematous disorders. J. Lab. Clin. Med. 98:1-15. 